\title{
OSILASI TEREDAM PADA PEGAS DENGAN MEDIUM FLUIDA
}

\section{Muhammad Ruli Aulia1, Nurul Zannah' ${ }^{1}$ Siti Zakiah Annasir Darajat', Tirto Atmojo', Windi Karina $^{1}$}

\author{
${ }^{1}$ Program Studi Pendidikan Fisika, Fakultas Tarbiyah dan Keguruan, UIN Sunan Gunung Djati \\ Bandung, Indonesia \\ E-mail: mruliaulia95@gmail.com
}

\begin{abstract}
ABSTRAK
Osilasi berdasarkan redamannya terbagi menjadi tiga yaitu osilasi teredam ringan, teredam kritis dan teredam penuh. Penelitian ini menyelidiki fenomena osilasi teredam yang disebabkan oleh fluida pada beban yang digantungkan pada pegas. Metode yang digunakan adalah metode eksperimen dan analisis grafik. Pengambilan data dilakukan dengan menggunakan software Video Analysis Tracker. Hasil penelitian menunjukan gerakan osilasi teredam kritis terjadi pada beban yang digantungkan pada pegas dalam medium air. Osilasi beban dalam medium minyak mengakibatkan redaman penuh. Sedangkan osilasi beban dalam medium udara dapat mengakibatkan redaman ringan.
\end{abstract}

Kata kunci: osilasi teredam, fluida, video analysis tracker

\begin{abstract}
The oscillation based on its recon is divided into three namely lightweight, critically and fully-muted oscillating oscillation. This research investigates a muted oscillation phenomenon caused by fluid on the load hung on the spring. The methods used are experimental and graphic analysis methods. Data retrieval is done using Video Analysis Tracker software. The results of the study showed critical, critically-muted oscillation movements occurring at the load that was hung on the spring in the medium of water. The load oscillation in the oil medium results in full damping. While the load oscillation in the air medium can result in light attenuation.
\end{abstract}

Keywords: damp oscilation, fluid, tracker video analyse

DOI: $\underline{\text { http://dx.doi.org/10.15575/itlp.v3i1.65479 }}$

Received: 10 Juli 2018 ; Accepted: 15 Agustus 2018 ; Published: 1 September 2018 


\section{PENDAHULUAN}

Getaran merupakan gerakan osilasi dari suatu sistem yang dapat berupa gerakan beraturan dan berulang secara kontinu atau dapat juga berupa gerakan tidak beraturan atau acak. Ketika sebuah getaran atau osilasi terulang sendiri, ke depan dan ke belakang, pada lintasan yang sama, gerakan tersebut disebut periodik (Giancoli, 2001)). Gerak periodik yang terjadi secara teratur disebut gerak harmonis. Contoh bentuk sederhana dari gerak periodik adalah benda yang berosilasi pada ujung pegas (Susilo, 2012).

Osilasi teredam

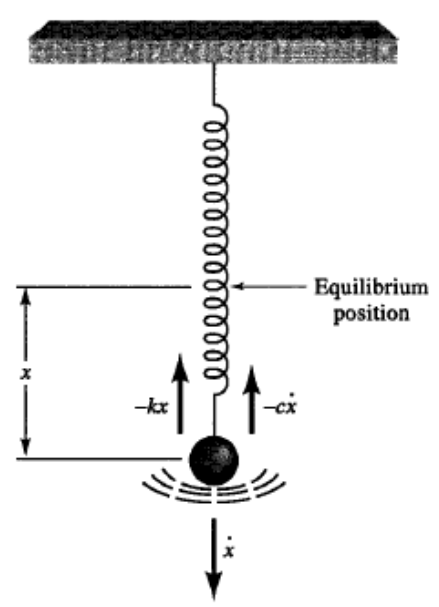

Gambar 1. Osilasi harmonik teredam

Beban yang digantungkan pada pegas dan berosilasi dengan $x$ adalah perpindahan dari kesetimbanganya, maka pada sistem tersebut terdapat gaya pemulih yang besarnya sebanding dengan jarak sistem dari posisi setimbangnya adalah $-k x$. Gaya tersebut akan cenderung mengembalikan sistem pada posisi setimbangnya. Apabila tidak ada gaya gesek maka pegas akan terus berosilasi tanpa berhenti. Pada kenyataannya amplitudo osilasi perlahan-lahan akan berkurang dan pada akhirnya osilasi akan berhenti. Berkurangnya amplitudo biasanya disebabkan oleh hambatan udara dan gesekan internal pada sistem yang berosilasi, maka dalam kasus ini terdapat gaya hambat yaitu $-c \dot{x}$ yang mana c merupakan konstanta hambatan.
Sehingga diperoleh persamaan diferensial gerak yaitu

$$
m \ddot{x}=-k x-c \dot{x}
$$

atau

$$
m \ddot{x}+k x+c \dot{x}=0
$$

sama dengan kasus yang tidak terdapat hambatan, maka persamaan ini kita bagi dengan $m$ sehingga diperoleh persamaan umum gerak

$$
\ddot{x}+\frac{c}{m} \dot{x}+\frac{k}{m} x=0
$$

jika kita subsitusikan faktor redaman $\gamma$ maka deperoleh

$\gamma=\frac{c}{2 m}$
Subsitusikan $\omega_{0}{ }^{2}=\frac{k}{m} \quad$ ke persamaan umum gerak sehingga menghasilkan

$$
\ddot{x}+2 \gamma \dot{x}+\omega_{0}^{2} x=0
$$

Adanya kecepatan yang bergantung pada hambatan $2 \gamma \dot{x}$ akan mempersulit permasalahan dan tidak bisa diselesaikan dengan solusi sinus cosinus. Maka cara yang lebih mudah adalah menggunakan metode persamaan diferensial orde kedua dengan koefisien konstanta. D sebagai diferensial dari $\frac{d}{d t}$. Operasikan pada $x$ dengan fungsi kuadrat dari $D$ sehingga diperoleh persamaan

$$
\left[D^{2}+2 \gamma D+\omega_{0}^{2}\right] x=0
$$

dengan menggunakan teorema binomial maka diperoleh

$\left[D+\gamma-\sqrt{\gamma^{2}-\omega_{0}^{2}}\right]\left[D+\gamma+\sqrt{\gamma^{2}-\omega_{0}^{2}}\right] x=0$ solusi umum dari jumlah masing-masing diferensial orde pertama adalah

Yang mana

$$
x(t)=A_{1} e^{-(\gamma-q)^{t}}+A_{2} e^{-(\gamma-q)^{t}}
$$

$$
q=\sqrt{\gamma^{2}-\omega_{0}^{2}}
$$

Terdapat tiga kategori untuk karakteristik akarakarnya yaitu (Fowles, 2005)

1. q real $>0$, sistem dikatakan Overdamping

2. $q$ real $=0$, sistem dikatakan Critical damping

3. $q$ imaginary, sistem dikatakan Underdamping

menurut H.J.Pain dalam buku The Physics of Vibration and Waves Sixth Edition (Pain, 2005):

1. jika $\quad \frac{s}{m}>\frac{r^{2}}{4 m^{2}} \quad$ sistem dikatakan underdaming 
2. jika $\frac{s}{m}=\frac{r^{2}}{4 m^{2}} \quad$ sistem dikatakan Critical damping

3. Jika $\frac{s}{m}<\frac{r^{2}}{4 m^{2}}$ sistem dikatakan over damping (4)

Penelitian yang dilakukan oleh Djoko Untoro menunjukan fenomena osilasi teredam yang disebabkan oleh batang kayu yang diberi magnet berayun didekat batang alumunium (Suwarno, 2015) Pada penelitian tersebut besarnya redaman merupakan fungsi jarak antara magnet dan alumunium. Osilasi yang terjadi berupa osilasi teredam ringan, teredam penuh dan teredam kritis. Penelitian ini menyelidiki fenomena osilasi teredam yang disebabkan oleh fluida pada beban yang digantungkan pada pegas.

\section{METODE PENELITIAN}

Metode yang digunakan adalah metode eksperimen dan analisis grafik. Peralatan yang digunakan adalah beban, pegas, statif, gelas ukur, penggaris, neraca empat lengan, neraca pegas, hygrometer thermometer, perekam video,dan fluida (udara, air ,dan minyak) serta software Video Analysis Tracker.

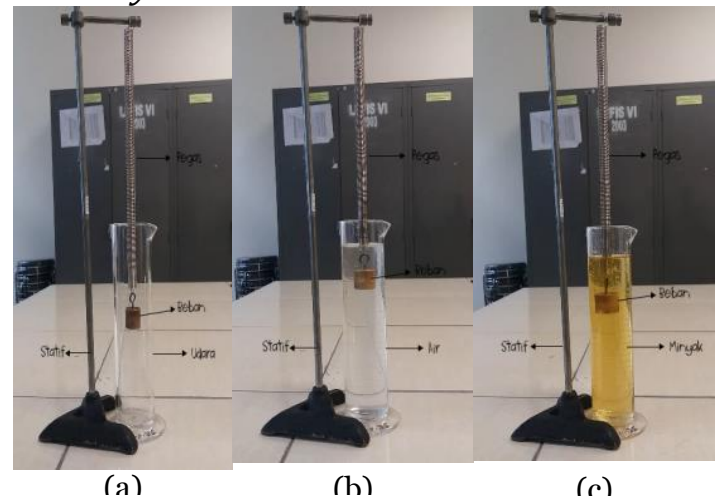

Gambar 2. Percobaan osilasi teredam pada (a) udara (b) air (c) minyak

Beban digerakkan dengan memberikan simpangan sebesar 0,009 m pada setiap fluida. Jenis fluida yang digunakan adalah udara, air dan minyak. Gerakan beban yang berosilasi dalam masing-masing fluida direkam dengan menggunakan perekam video. Pengambilan data dilakukan dengan menggunakan software Video Analysis Tracker. Dalam mencari posisi arah vertikal setiap satuan waktu dilakukan penandaan posisi beban dan hasilnya berupa grafik posisi terhadap waktu. Pengolahan data percobaan dilakukan dengan menggunakan aplikasi Ms. Excel. Kemudian dilakukan analisis untuk mengetahui jenis redaman yang terjadi pada benda dalam udara, air dan minyak.

\section{HASIL DAN PEMBAHASAN}

Dari percobaan diperoleh data seperti pada gamabar 3 berikut:

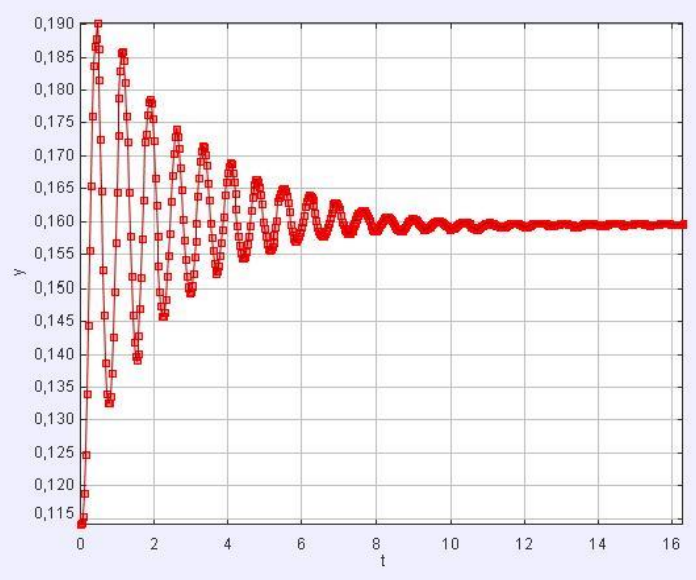

Gambar 3. Osilasi pada medium air Grafik yang ditunjukkan pada gambar 3 menunjukan gerakan osilasi pada medium air yaitu osilasi teredam kritis, maka dari itu terlihat adanya beberapa gelombang yang terjadi sebelum berhenti. Osilasi teredam kritis salah satu cirinya adalah pengurangan amplitudo yang semakin kecil seiring bertambahnya waktu.

Tabel 1. Data hasil percobaan osilasi pada air

\begin{tabular}{cccc}
\hline Besaran & Nilai & Besaran & Nilai \\
\hline$m$ & 0,04 & $F$ & 0,5 \\
$k$ & 5,38 & $c$ & 0,96 \\
$\Delta x$ & 0,09 & $r$ & 9,86 \\
$v$ & 0,03 & $r^{2}$ & 97,1 \\
$a$ & 0,3 & $\omega$ & 110 \\
\hline
\end{tabular}

Dengan $k$ merupakan konstanta pegas dengan satuan $(\mathrm{N} / \mathrm{m}), m$ massa beban dalam $\mathrm{kg}, \Delta x$ perubahan panjang pegas dalam $\mathrm{m}, v$ cepat rambat gelombang dalam $\mathrm{m} / \mathrm{s}, a$ percepatan dalam $\mathrm{m} / \mathrm{s}^{2}, F$ gaya dengan satuan $\mathrm{N}, c$ konstanta 
redaman dalam $\mathrm{kg} / \mathrm{s}$, dan $r$ konstanta redaman per satuan massa.

Berdasarkan Tabel 1 nilai $\omega^{2}>r^{2}$, ini tidak sesuai dengan teori yang ada karena pada osilasi teredam kritis $\omega^{2}=r^{2}$. Selisih nilai $\omega^{2}$ dan $r^{2}$ relatif kecil hal tersebut bisa diakibatkan karena nilai ketidakpastian pada $k$ dan $F$.

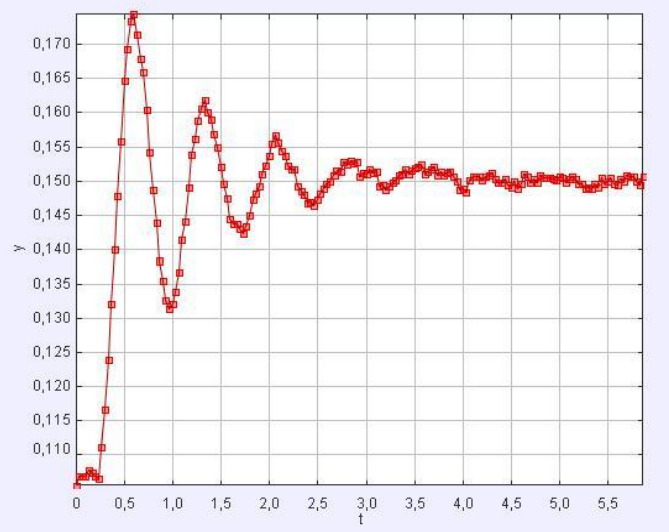

Gambar 4. Osilasi pada medium minyak Grafik yang ditunjukkan pada gambar 4 menunjukan gerakan osilasi pada medium minyak yaitu osilasi teredam penuh, maka dari itu benda mengalami redaman yang besar sehingga benda hanya melakukan sedikit gerak osilasi sebelum akhirnya berhenti dan untuk kembali ke titik setimbangnya memerlukan waktu yang lama.

Tabel 2. Data hasil percobaan osilasi pada medium Minyak

$\begin{array}{cccc}\text { Besaran } & \text { Nilai } & \text { Besaran } & \text { Nilai } \\ m & 0,0487 & F & 0,5 \\ k & 5,38 & c & 24,7 \\ \Delta x & 0,093 & r & 253 \\ v & 0,03793 & r^{2} & 64200 \\ a & 0,387 & \omega & 110\end{array}$

Berdasarkan tabel 2 nilai $\omega^{2}<r^{2}$ ini menunjukan bahwa osilasi pada medium minyak termasuk teredam penuh.

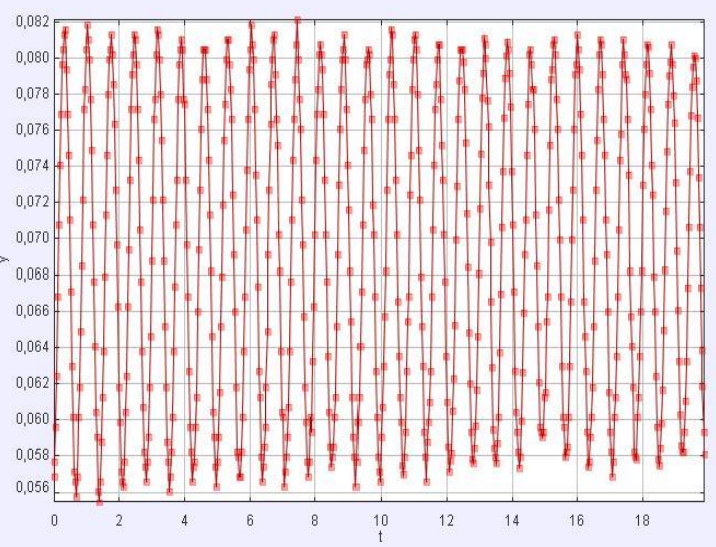

Gambar 5. Osilasi pada medium udara Grafik yang ditunjukkan pada gambar 5 menunjukan gerakan osilasi pada medium udara yaitu osilasi teredam ringan, maka dari itu benda melakukan lebih banyak gerakan osilasi sebelum akhirnya berhenti

Tabel 3. Data hasil percobaan osilasi pada medium udara

$\begin{array}{cccc}\text { Besaran } & \text { Nilai } & \text { Besaran } & \text { Nilai } \\ m & 0,0487 & F & 0,5 \\ k & 5,38 & c & 0,939 \\ \Delta x & 0,093 & r & 9,647 \\ v & 0,06655 & r^{2} & 93,079 \\ a & 0,60089 & \omega & 110\end{array}$

Berdasarkan tabel 3 nilai $\omega^{2}>r^{2}$ ini menunjukan bahwa osilasi pada medium udara termasuk teredam ringan.

Menurut data pada ketiga tabel, koefisien redaman terbesar pada medium minyak. Dengan demikian gaya hambat minyak lebih besar dari gaya hambat air dan udara. Makin besar konstanta redaman, maka semakin lama waktu yang diperlukan sistem untuk kembali ke posisi setimbang

\section{KESIMPULAN}

Dari penelitian yang telah dilakukan ini dapat diambil kesimpulan bahwa penerapan metode tracking video menggunakan software tracker dan secara perhitungan untuk menentukan nilai kecepatan sesaat pada lintasan yang berbeda 
telah berhasil dilakukan. Nilai kecepatan sesaat pada lintasan yang licin lebih besar dari pada pada lintasan kasar. Dengan nilai kecepatan sesaat pada gerak parabola di lintasan licin adalah $1,431 \mathrm{~m} / \mathrm{s}$ dan di lintasan kasar adalah 1,323 m/s. Sedangkan dengan menggunakan tracker nilai kecepatan sesaat pada gerak parabola di lintasan licin adalah $1,712 \mathrm{~m} / \mathrm{s}$ dan di lintasan kasar adalah $1,589 \mathrm{~m} / \mathrm{s}$.

\section{DAFTAR PUSTAKA}

Fowles, Grant R dan Cassiday, George L. Analytical Mechanics Seventh Edition. Belmont: Thomson Brooks/Cole, 2005. 0-53449492-7.

Pain, H.J. The Physics of Vibrations and Waves. England : Jhon Wiley \& Sins,Ltd, 2005.

Giancoli, D. C. FISIKA Edisi Kelima Jilid 1. Jakarta : Erlangga, 2001.

Susilo, A., Yunianto, M., Variani, V. I., 2012. Simulasi Gerak Hrmonik sederhana dan Osilasi Teredam pada Cassy-E 524000. Indonesian Journal of Applied Physics, hal. 124-137.

Suwarno, D., 2015. Getaran osilasi teredam pada pendulum dengan magnet dan batang alumunium. prosiding $S K F$, hal. 100-107. 